\title{
Corporate Social Responsibility in Improving Customer Satisfaction Through Corporate Image at PT. Bank Mandiri (Persero) Malang City, Indonesia
}

\author{
Sihwahjoeni \\ Faculty of Economics and Business, University of Merdeka Malang \\ Indonesia
}

\begin{abstract}
A bank will win the competition if it can create value and give satisfaction to customers through the delivery of quality services. A superior bank is a bank that deftly manages business changes and can take advantage of existing opportunities with something that is effective and efficient, one of which is by creating a positive bank image or image of the product or service produced by the bank. This study aims to analyze the effect of corporate social responsibility on corporate image, analyze the influence of corporate social responsibility on customer satisfaction, analyze the influence of corporate image on customer satisfaction and analyze the effect of corporate social responsibility on customer satisfaction through a corporate image. The sample in the study amounted to 100 customers. Analysis techniques use path analysis. The results of the analysis show that corporate social responsibility influences the company's image, which means that by implementing corporate social responsibility activities it can enhance the company's image. Corporate social responsibility affects customer satisfaction. The company's image influences customer satisfaction, meaning that with the presence of corporate social responsibility activities, it can increase customer satisfaction at PT. Bank Mandiri (Persero) Malang City. The company's image mediates the effect of corporate social responsibility on customer satisfaction. This means that customer satisfaction can be created if it has a good corporate image by implementing corporate social responsibility activities that relate to economic, social and environmental issues.
\end{abstract}

Keywords: Corporate Social Responsibility, Corporate Image, Customer Satisfaction.

\section{INTRODUCTION}

Independent bank is one bank that is developing in Malang and a new retail bank that is a combination of several pieces of the Bank, the Bank Bumi Daya, Export Import Bank, Bank of Commerce and Bank Pembangunan Indonesia country. independent bank is one of the ranks of the largest banks in Indonesia and the Bank are most in demand by the public in Malang either among workers or students. Customer satisfaction is important in a PT. Bank Mandiri (Persero) Malang because by retaining customers means increased profits and sustain PT. Bank Mandiri (Persero) Malang [1].

Approach to corporate social responsibility is the right strategy in maintaining customer satisfaction, because by implementing a program of Corporate Social Responsibility (CSR) in PT. Bank Mandiri (Persero) Malang will give you the benefits of integrated and sustainable economic, social and environmental. CSR is now not just a social responsibility but also liabilities and bank concern about the economic, social and environment around the location of the bank is located. CSR activities undertaken by PT. Bank Mandiri (Persero) Malang can be direct or indirect effect on customer satisfaction with the mediation of the company's image. If the CSR activities conducted at PT. Bank Mandiri (Persero) Malang positive impact on the corporate image of the customer satisfaction will increase [2].

The image of the company, is an important element that is widely recognized influence customer satisfaction. Corporate image has an important role in the industry PT. Bank Mandiri (Persero) Malang. The creation of a positive corporate image in the eyes of customers can achieve a sustainable advantage in a competitive environment and CSR is an essential tool for creating a positive corporate image. With the CSR activities of PT. Bank Mandiri (Persero) Malang will benefit from an integrated and sustainable through economic, social and environment can enhance good corporate image [2].

The inclusion of the corporate image in the framework of customer satisfaction not only can improve the predictive power of the model but also can provide a deeper understanding of the factors that create customer satisfaction in the industry PT. Bank Mandiri (Persero) Malang.

This study aimed to analyze the influence of corporate social responsibility to corporate image, analyze the impact of corporate social responsibility to customer satisfaction, analyzing the influence of corporate image on customer satisfaction and analyze the influence of corporate social responsibility to customer satisfaction through the corporate image. 


\section{LITERATURE REVIEW}

Customer satisfaction is basically related to the level of one's feelings after comparing the performance or results which he felt to his expectations. Kotler defined satisfaction as "a person's feelings of pleasure or disappointment the resulting from comparing a product's perceived performance (or outcome) in relation to his or her expectations" [3]. The level of satisfaction is a function of the difference between the performance he felt with expectations. Customers can grasp one of general satisfaction rate, ie if performance is below expectations, then the consumer will be disappointed, as expected performance, then the consumer will be satisfied, and the performance exceeded expectations, then the consumer will be very satisfied.

According Jasfar of customer satisfaction with a service is: A comparison between the perceptions of the services received by expectations before using the services [4]. If hopes terlampui, means those services have made an exceptional quality and will also lead to a very high satisfaction (very satisfy). Conversely, if their expectations are not achieved, then it means that service quality does not meet what is desired or the company failed to serve the consumer. If the expectation is similar to what is obtained, the consumer was satisfied (satisfy). Indicator of satisfaction according to Tjiptono attributes forming satisfaction consists of: Conformity of expectations, is a combination of the ability of a product or service and promotion that is relied upon, so that a product produced can be in accordance with what the manufacturer promised; ease in obtaining, products or services offered by producers available at outlets and stores that are close to potential buyers; and willingness to recommend, the willingness of customers to recommend products or services to friends or family is an important measure to analyze and act upon $[5]$.

Wibisono states that if a company wants to survive, then it must pay attention to the 3P (Profit, People, Planet) [6]. In addition to the pursuit of profit (profit), the company must also pay attention and be involved in the fulfillment of public welfare (people), and contribute actively to protecting the environment (planet). The third component of this is often used as a basis for planning, implementation and evaluation (reporting) programs of corporate social responsibility. Through corporate social responsibility worse social impact can be prevented either directly or indirectly, of the continuity of the business, because CSR itself is very important not only for society but also for the company itself.

Suharto, the notion of CSR relatively more easily understood and operationalized is to develop the concept of the Triple Bottom Line (Profit, Planet, People), good companies not only hunt advantage mere economic (profit), but have concern for the welfare of the community ( people) and play an active role in protecting the environment (planet) [7].

Corporate imageaccording to Kotler and Keller, namely: the image is a set of beliefs, ideas, and impressions of a person against an object [8]. Meanwhile, according to Gregory \& Wiechmann, that corporate image is a combination of the impact on the observer of all the components of verbal and visual companies either planned or not, or from other external influences [9]. According to Harrison, complete information about the company's image includes four elements as follows: Personality, Reputation, Value and Corporate identity [10].

\section{CONCEPTUAL FRAMEWORK AND HYPOTHESES}

\subsection{Influence of CSR to Corporate Image}

Corporate imageis a belief, experience, information, emotions associated with a stand-alone company and the impression in the public mind [11]. For the company, the customer has an important role. Through the creation of a positive corporate image in the eyes of customers, the company can achieve a sustainable competitive advantage in a competitive environment. Assessment of the corporate image to the public can form images of good and bad. Good image appear as a result of assessment or public response to events, concerns, accomplishments and reputation of the company during its operation. Corporate image in research using indicators Harrison, which consists of personality, reputation, values and corporate identity [10]. Furthermore, Corporate Social Responsibility is an essential tool for creating a corporate image that is positive, this is because the company strives to create a positive impression of the company to influence their market share through social responsibility activities are not only looking for profit (profit) but also able to improve the welfare of the surrounding community ( People), concerned with the preservation of the environment and use environmentally friendly technologies (Planet). This study coincides with findings Florencio et al, Gurlek \& Duzgun which states that CSR affect the corporate image [12], [2]. Based on these descriptions can be formulated hypotheses: this is because the company strives to create a positive impression of the company to influence their market share through social responsibility activities are not only looking for profit (profit) but also able to improve the welfare of the surrounding community (People), concerned with the preservation of the environment and use environmentally friendly technologies (planet). This study coincides with findings Florencio, Del Junco, Verdugo, and Diaz; Gurlek \& Duzgun which states that CSR affect the corporate image [12], [2]. Based on these descriptions can be formulated hypotheses: this is because the company strives to create a positive impression of the company to influence their market share through social responsibility activities are not only looking for profit (profit) but also able to improve the welfare of the surrounding community (People), concerned with the preservation of the environment and use environmentally friendly technologies ( planet). This study coincides with findings Florencio et al, and; Gurlek \& Duzgun which states that CSR affect the corporate image. Based on these descriptions can be formulated hypotheses: care for the preservation of the environment and use environmentally friendly 
technologies (Planet). This study coincides with findings Florencio et al and Diaz; Gurlek \& Duzgun which states that CSR affect the corporate image [12], [2]. Based on these descriptions can be formulated hypotheses: care for the preservation of the environment and use environmentally friendly technologies (Planet). This study coincides with findings Florencio et al; Gurlek \& Duzgun which states that CSR affect the corporate image [12], [2]. Based on these descriptions can be formulated hypotheses:

$\mathrm{H}_{1}$ : CSR affect the corporate image.

\subsection{The influence of CSR on Customer Satisfaction}

Tjiptono, suggests that customer satisfaction is an evaluation purnabeli where selected alternatives at least provide the results (outcomes) equal or exceed customer expectations, while dissatisfaction arises when the results do not meet expectations [13]. According Lupiyoadi, the expectations of the customers basically the same as what kind of services should be provided by the company to the customer [14]. Expectations of customers is based on information conveyed by word of mouth, personal needs, past experience, and external communications (advertising and other forms of promotion of other companies). Applying CSR in the tourism industry will reap the benefits of integrated and sustainable economic, social and environmental. By implementing CSR negative impacts of the operations of the tourism industry can be overcome, a positive corporate image in the eyes of customers will cause a good impression, customer confidence is critical in influencing consumer purchasing power so that these components influence on customer satisfaction. customerrecommends that more attention to the tourism industry social problems to other people, have a good impression and trustworthy. This situation creates customer loyalty and is very important in terms of ensuring the loyalty of new customers. This study coincides with findings Khaeril et al. which states that the CSR effect on customer satisfaction [15]. Based on these descriptions can be formulated hypotheses:

$\mathrm{H}_{2}$ : CSR impact on customer satisfaction.

\subsection{Influence of Corporate Image on Customer Satisfaction}

Customer satisfaction according to Kotler is feeling happy or disappointed someone comes after comparing the perception or impression of the performance of a product and expectations [3]. The level of satisfaction is a function of the difference between the performance he felt with expectations. Customers can grasp one of general satisfaction rate, ie if performance is below expectations, then the consumer will be disappointed, as expected performance, then the consumer will be satisfied, and the performance exceeded expectations, then the consumer will be very satisfied. Maintaining customer satisfaction means to gain more advantage over their competitors because customer satisfaction is a critical component that enables the company to profit and ensure business continuity. Through customer satisfaction, the banking industry can gain a sustainable competitive advantage. A positive corporate image in the eyes of customers will cause a good impression thus affecting the purchasing power of consumers so that these components influence on customer satisfaction. Customer recommended banking industry pay more attention to social problems to other people, have a good impression and trustworthy. This study coincides with findings Khaeril which states that the corporate image of an effect on customer satisfaction [15]. Based on these descriptions can be formulated hypotheses: Customer recommended banking industry pay more attention to social problems to other people, have a good impression and trustworthy. This study coincides with findings Khaeril which states that the corporate image of an effect on customer satisfaction [15]. Based on these descriptions can be formulated hypotheses: Customer recommended banking industry pay more attention to social problems to other people, have a good impression and trustworthy. This study coincides with findings Khaeril, which states that the corporate image of an effect on customer satisfaction [15]. Based on these descriptions can be formulated hypotheses:

H3: Corporate image effect on customer satisfaction.

\subsection{CSR Impact of Customer Satisfaction Through Corporate Image}

Customer satisfaction should be maintained if a banking industry wants to remain alive and sustainable. By implementing CSR, the banking industry will reap the benefits of integrated and sustainable economic, social, environmental. The banking industry that implement CSR will also improve the corporate image. So we can conclude that CSR activities oriented to the corporate image will create customer satisfaction. Based on these descriptions can be formulated hypotheses:

H4: CSR affects on customer satisfaction through the corporate image

The linkage between the variables used in this study can be described in the conceptual framework as follows: 


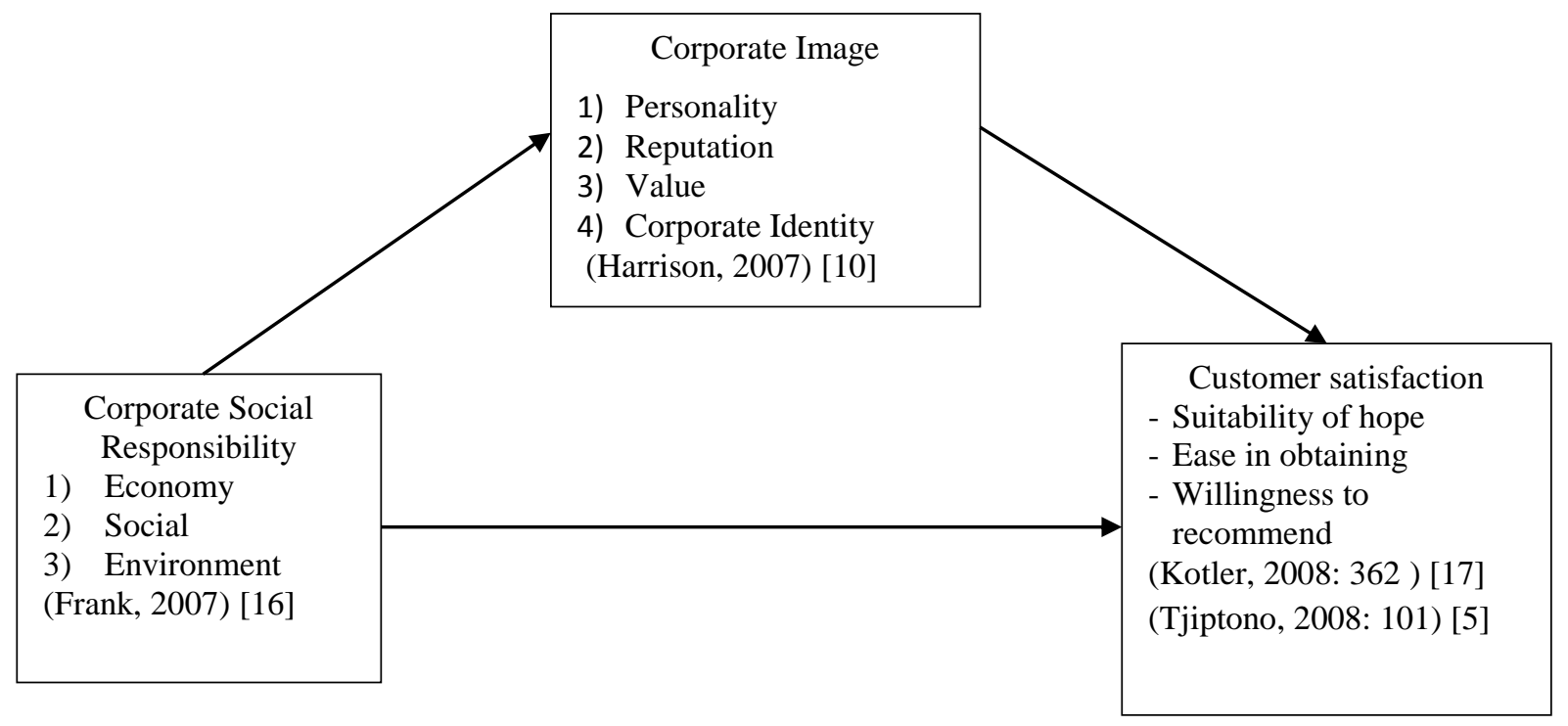

Figure 1. Conceptual Framework

\section{RESEARCH METHODS}

\subsection{Design Research}

This study is the explanation (explanatory research). Explanatory research is intended to clarify or explain a phenomenon, explain relationships, examine the influence between variables (including causality of the relationship).

\section{4,2. Operational Definition of Variables}

1. Customer satisfaction is the attitude of the customer after the Bank enjoys services. Indicators used suitability expectations, the ease in obtaining and willingness to recommend

2. CSR is one of the programs that can be done to make concern for the company's customers and the local community. The indicators used in this study are: economic, social, environmental.

3. Corporate imageis the impression that someone from the experience of using the services and measurable indicators: personality, reputation, values, corporate identity. Trust is the confidence of customers to use the services. The indicators used in this study are: honesty, virtue, competence.

\subsection{Population and Sample}

Population and sample in this study were all customers of PT. Bank Mandiri Malang numbering 13,122,428 customers. The number of samples in this study were taken as many as 100 customers is calculated using the formula Slovin. The sampling technique used Probability Sampling by simple random sampling.

\subsection{Data analysis technique}

Data analysis in this research using descriptive analysis and pathway analysis. Model equation of the study can be formulated as follows:

$\mathrm{Y} 1=\mathrm{b} 1 \mathrm{x} 1+\mathrm{e}$

$\mathrm{Y} 2=\mathrm{b} 2 \mathrm{X} 1+\mathrm{b} 3 \mathrm{Y} 1+\mathrm{e}$

Information:

$\mathrm{X} \quad=$ Corporate Social Responsibility

Y1 $=$ Corporate Image

Y2 = Customer satisfaction

$\mathrm{b} 1 \ldots \mathrm{b} 3=$ Coefficient

$\mathrm{e}=$ Error 
International Journal of Advances in Scientific Research and Engineering (ijasre), Vol 5 (11), November-2019

\section{RESEARCH RESULT}

\subsection{Description of Respondents}

The number of respondents in this study as many as 100 customers of PT. Mandiri (Persero) Malang. Each respondent had different characteristics. Therefore, it is necessary grouping with certain characteristics. The following will be presented descriptively respondent data based on characteristics:

Table 1. Characteristics of Respondents

\begin{tabular}{lcc}
\hline \multicolumn{2}{c}{ Number of people) } & Percentage (\%) \\
\hline Gender & 59 & 59 \\
Man & 41 & 41 \\
Woman & & \\
\hline Age & 26 & 26 \\
20-30 years & 54 & 54 \\
31-40 years & 20 & 20 \\
41-50 years & & \\
\hline Work & 29 & 29 \\
PNS & 24 & 24 \\
College student & 21 & 21 \\
Entrepreneur & 26 & 26 \\
Private & &
\end{tabular}

\subsection{Validity and Reliability Test Results}

Based on the validity of the testing that has been done on the items acquired questions probability value smaller than $\alpha=$ 0.05 . This shows that the whole item questionnaire questions used preformance is valid or actually able to measure what should be measured. Based on the reliability test results show that the variables of CSR, corporate image, and customer satisfaction has a reliability coefficient greater than 0.60 so based on a reliability test instrument are eligible to be used in this study.

\subsection{The influence of CSR on Customer Satisfaction with Corporate}

Testing the hypothesis in this study was conducted with path analysis, using simple regression and multiple regression then do filtering based on statistical tests and significance. Statistical test can be done by using the coefficient regression coefficient and standard error. If a significant regression coefficient means a significant path coefficient value is not significant whereas a significant dibuang.Uji can be done by comparing a significant pathway. If the value is significantly smaller path coefficient of 0.05 , the coefficient is significant. And if the value of the path coefficient greater than 0.05 , the coefficient is not significant. To see the impact of CSR on customer satisfaction through the corporate image are summarized in table 2.

Table 2

Effect of Direct, Indirect Influence and Effects of Total Path Analysis Results

\begin{tabular}{lccccc}
\hline \multicolumn{1}{c}{ variables } & Direct Effect & $\mathrm{T}$ & $\mathrm{p}$-value & Indirect Effect & Total Effect \\
\hline CSR $\rightarrow$ Corporate Image & 0.577 & 6.990 & $0.000 *$ & - & - \\
CSR $\rightarrow$ customer satisfaction & 0.216 & 2.447 & $0.016 *$ & - & - \\
Corporate Image $\rightarrow$ customer satisfaction & 0.556 & 6.292 & $0.000^{*}$ & - & - \\
CSR $\rightarrow$ Corporate Image $\rightarrow$ customer satisfaction & 0.216 & - & - & 0.577 X $0.556=$ & 0.537 \\
& & & & 0.321 &
\end{tabular}

Sources: Primary data is processed

Based on Table 2, it appears that the total effect of CSR on customer satisfaction variable (0.537) is greater than the direct effect (0.216). These results indicate that the corporate image of the status as an intervening variable in the effect of CSR on customer satisfaction, because the total value is greater than from the direct influence.

\subsection{Hypothesis testing}

Based on Table 2, Effect of CSR to corporate image is significant with CSR regression coefficient of 0.577 and $t$ value of 6.990 with $p$ value of 0.000 . This means that CSR significant effect on corporate image, increase in CSR will be followed by an increase in corporate image. Thus the first hypothesis stating that CSR affect the corporate image is statistically proven. 
Based on Table 2, the effect of CSR on customer satisfaction is significant with 0.216 regression coefficient and $t$ value of 2.447 and $p$ value of 0.016 . This means that CSR significant effect on customer satisfaction, which means an increase in CSR will be followed by an increase in customer satisfaction. Thus the second hypothesis is statistically proven

The influence of corporate image on customer satisfaction is significant with regression coefficient $\mathrm{t}$ values of 0.566 and 6.292 and a p-value of 0.000 . This means that corporate image significant effect on customer satisfaction, which means an increase in corporate image will be followed by an increase in customer satisfaction. Thus the third hypothesis is statistically proven.

Based on Table 2 results of the analysis showed that the corporate image of the status as an intervening variable in mediating variable CSR on customer satisfaction, because the larger the total value (0.537) of direct influence (0.216). Thus the third hypothesis which states that CSR has a significant effect on customer satisfaction through the corporate image of statistically proven.

Based on the description of hypothesis testing, then compiled trajectory models in the path analysis in Figure 2 below.

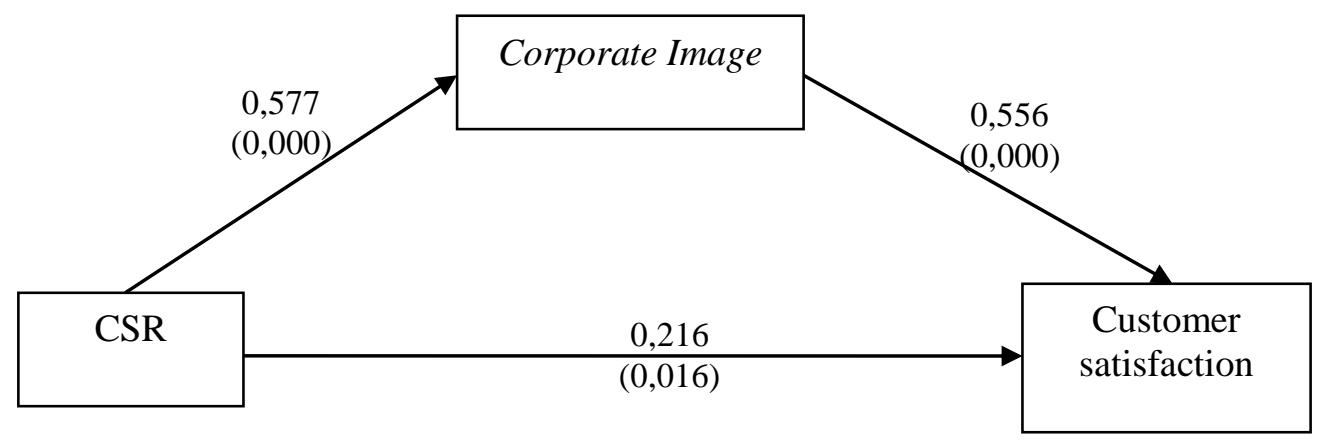

Figure 2 Research Model

\section{DISCUSSION}

\subsection{Influence CSR to Corporate Image}

CSR take effect against corporate image, which means that CSR is implemented to improve corporate image, because one of the benefits of CSR is a positive corporate image. CSR programs implemented by PT. Bank Mandiri (Persero) Malang has a role in shaping the image of the company. With CSR programs undertaken PT. Bank Mandiri (Persero) Malang became known to the public as a company that cares about people and the environment, the community can learn more about PT. Bank Mandiri (Persero) Malang because of the consistency of the company in social activities and it is the company's assets for PT. Bank Mandiri (Persero) Malang. By doing the CSR program makes PT. Bank Mandiri (Persero) Malang is able to deliver one of the values that characterize the company's enterprise, which is of concern to the recipients of the CSR program and shape the perception of the recipient of the characteristics of the company. PT. Bank Mandiri (Persero) Malang CSR programs with a view to preserving the company's corporate image. Some awards have been achieved by PT. PT. Bank Mandiri (Persero) Malang associated with CSR programs. Of CSR, PT. Bank Mandiri (Persero) Malang earned a reputation as a company that performs and manages the company with good CSR program. The recipients of the CSR program conducted by PT. Bank Mandiri (Persero) Malang assume that PT. Bank Mandiri (Persero) Malang CSR programs with good company and well coordinated that make up corporate image. The company's image is not only seen from a person's personality or personal response, but also influenced by other factors such as the company's reputation in the community. This is consistent with the results of research Gurlek \& Duzgun; Florencio et al. which states that CSR affect the corporate image [2, 12],

\subsection{The influence of CSR on Customer Satisfaction}

CSR effect on customer satisfaction, which means that the implementation of CSR conducted in PT. Bank Mandiri (Persero) Malang can improve customer satisfaction. It is addressing that customer satisfaction can be improved through increased CSR.CSR activities that include economic, social and environmental certainly create customer satisfaction though not provide immediate benefits. CSR can be used as a tool to create customer satisfaction. This is consistent with the results of research Gurlek \& Duzgun which states CSR effect on customer satisfaction [2].

\subsection{Influence of Corporate Image on Customer Satisfaction}

Corporate image effect on customer satisfaction, which means that the better corporate image can improve customer satisfaction. Corporate Image an impression of an organization that is based on knowledge and experience. Discussion of the corporate image is divided into personality, reputation, values / ethics, corporate identity. If the dimensions of the well, it can be said that the 
company's good image. Therefore, PT Bank Mandiri (Persero) seeks to increase the dimensions of the Corporate Image to get a good Corporate Image.

\subsection{The influence of CSR on Customer Satisfaction with Corporate Image}

CSR programs implemented by PT. Bank Mandiri (Persero) Malang can increase customer satisfaction if PT. Bank Mandiri (Persero) corporat Malang has a good image in the minds of consumers. Corporat image shows the impression of an object to another object that is formed by processing the information at any time from a variety of sources are reliable. Corporat good image is very important for continuity of PT. Bank Mandiri (Persero) Malang, because it would affect all elements in the PT. Bank Mandiri (Persero) Kota Malang, CSR is a pretty effective way to create and enhance the corporate image and customer loyalty. With increasing corporat image that has been achieved through CSR activities, PT. Bank Mandiri (Persero) Malang can contribute to the creation of customer satisfaction.

\section{CONCLUSIONS AND RECOMMENDATIONS}

The main objective of this study was to prioritize how CSR role in creating customer satisfaction through the corporate image of PT. Bank Mandiri (Persero) Malang. This study has found that corporate image has a mediating role in the relationship between CSR and customer satisfaction, and the relationship between these variables has been explained by a model study of direct and indirect relationships. Based on the results of this research indicate that PT. Bank Mandiri (Persero) Malang should do more CSR activities connected on social issues and the environment. In addition, the direct effect of CSR on customer satisfaction is lower than the indirect effect obtained through the corporate image. Therefore, if PT. Bank Mandiri (Persero) Malang wanted to create customer satisfaction through CSR, the Bank should introduce CSR activities to its customers. If customers believe that PT. Bank Mandiri (Persero) Malang responsible economically, socially and environmentally most likely, customers will also have a positive impression (corporate image) about PT. Bank Mandiri (Persero) Malang and this will increase customer satisfaction.

\section{RECOMMENDATIONS}

For Bank should if you want to create and maintain customer satisfaction through CSR, the CSR activities conducted at PT. Bank Mandiri (Persero) Malang more attention to issues of environmental, economic and social. By way of introducing CSR activities through websites, social media and other media. Furthermore, for advanced research in order to be able to add other mediating variables that can increase customer satisfaction.

\section{REFERENCE}

1. Aksu. A. (2006). Gap analysis in customer layalty: a research in 5-star hotela in the Antalya region of Turkey. Quality and Quantity. Vol. 40 No.2. 187-205.

2. Gurlek. M.. \& Duzgun, E. (2017). How does corporate social responsibility create customer loyalty? The role of corporate image. Social Responsibility Journal. Vol. 13 No. 3. 409-427.

3. Kotler, P. (2004). Marketing Management. The Millenium Edition. Englewood Cliffs. New Jersey : Prentice Hall.

4. Jasfar, F. (2005). Manajemen jasa. Cetakan Pertama. Bogor: Ghalia Indonesia

5. Tjiptono, F. (2008). Strategi Pemasaran. Edisi III. Yogyakarta: Penerbit CV. Andi Offset.

6. Wibisono. Y. (2007). Membedah Konsep \& Aplikasi CSR (Corporate Social Responsibility). Jakarta: PT Gramedia.

7. Suharto, E. (2010). CSR \& COMDEV Investasi Kreatif Perusahaan di Era Globalisasi. Bandung: Alfabeta.

8. Kotler, P.. \& Keller, K. L. (2012). Managemen Pemasaran. Edisi 12. Jakarta: Erlangga.

9. Gregory, J.. \& Wiechmann, J. (2011). Marketing Corporate Image: The Company as your number one product. New York: McGraw-Hill.

10. Harrison, S. (2007). Marketers Guide To Public Relations. New York: John Willwy And Sons. Inc.

11. Kim, S. S.. Lee. J. and Prideaux. B. (2014). Effect of celebrity endorsement on tourists perception of corporate image. corporate credibility and corporate loyalty. International Journal of Hospitality Management. 37.

12. Florencio. B.. Del Junco. J.. Verdugo, M.. \& Diaz, I. (2018). Trust as mediator of corporate social responsibility. image and loyality in the hotel sector. Journal of sustainable tourism. 1-18.

13. Tjiptono, F. (2006). Strategi Pemasaran. Yogyakarta: Andi Offset.

14. Lupiyoadi, H. (2006). Manajemen Pemasaran Jasa. Edisi Kedua. Jakarta : Penerbit Salemba Empat.

15. Khaeril, S. H. dan Sudirman, I. (2013). Pengaruh Kualitas Layanan. Corporate Social Responsibility (CSR) Terhadap Corporate Image Serta Implikasinya Terhadap Kepuasan dan Loyalitas Nasabah di PT.Bank Muamalat Indonesia Tbk.Cabang Makassar. Jurnal Manajemen. Vol 1 No 1 Halaman 1-14

16. Frank, J. (2005). Public Relations. Jakarta: Erlangga.

17. Kotler, P. (2008). Manajemen Pemasaran. Edisi 12 Jilid 2. Jakarta: Indeks. 